\title{
Expenses disclosure at BMA sparks review
}

\author{
Melanie Newman \\ London
}

The BMA has come under fire from members of its governing council after it emerged that until the practice was stopped earlier this year many senior officers had been taking spouses with them on trips abroad and reclaiming the costs as expenses, even though the BMA had no formal policy to permit it.

During this period the only senior officer officially allowed to be accompanied by his or her partner to some events and to claim for the associated costs was the BMA president. However, it recently became apparent that other senior officers were also reimbursed for spousal travel expenses in this way.

Chaand Nagpaul, who has been chair of the BMA's ruling council since 2017, instituted a ban on such expense claims after he became aware of them this January. He is now planning a wider review of the BMA's governance.

The scale of the payouts is not yet clear. The BMJ has been told that none of the current chief officers have been in receipt of such spousal travel expense payments. All previous beneficiaries have since left the association.

Doctors on the BMA's council had raised concerns about the reimbursements, arguing that such largesse was wrong at a time when rank and file members, including junior doctors and medical students, were having to cope with pay rises below inflation. A letter signed by around a dozen council members was sent to the BMA's governing board in March asking whether directors intended to seek repayment from the beneficiaries.

Nagpaul said, "There are understandably strong views that monies paid in this way should be reclaimed." The BMA has been advised that there was no legal obligation to repay, Nagpaul said, but he added it would be writing to those involved.

In a written statement to The BMJ, council members Sam Everington, Jacky Davis, Clare Gerada, Kailash Chand, and Emma Runswick expressed support for the chair's actions. "It is surprising and disappointing that some of the top leadership of the BMA claimed expenses for international travel by spouses," they said. "Ordinary members' subscriptions paid for those trips."

Gerada, who has sat on the council for three years, said, "The BMA, under the leadership of Dr Nagpaul, is committed to making sure that the organisation uses its members' money fairly, responsibly, and wisely.

"He is leading the organisation forward by tackling outdated practices and actively listening to concerns."

Another council member, Wendy Savage, praised her colleagues for bringing "these unsatisfactory governance matters" to light.
The BMA's board of directors, who are responsible for the management of the finances and general administration of the organisation, seemed to be unaware of the behaviour of the senior officers. J S Bamrah, who sat on the BMA's board for two years before stepping down in July 2018, said that he had "absolutely no idea" about the claims and that members would be "rightly aghast" to learn of them.

"I don't know how often it happened, but even once would be too many," he said.

This is not the first time that the medical union has been criticised for a lack of transparency over payments to its senior officials. In 2004 it emerged that some consultants had been claiming large sums, through an opaque process, in compensation for private practice earnings lost while doing BMA work. ${ }^{1}$ And in 2015 the revelation that senior figures had secretly awarded themselves pay hikes of up to $137 \%$ provoked an internal row. ${ }^{2}$

Nagpaul said that spousal expenses for senior officials other than the president did not appear to have fallen under any formal policy but that claims had been made according to "custom and practice."

"A search of our archives suggests that this practice may have been allowed in days gone by," he said. "It certainly wasn't current policy in 2017 when I became a chief officer. No one told me it was something I could do. Nor do I consider it an appropriate use of members' money."

Nagpaul has now banned all spousal expense claims, including for the BMA president. He added, "I intend, through the board, to have an independent assessment of our governance.

"When I became chair of council I found, as in many organisations which have been around for over a century, that there were elements of 'custom and practice' as well as a lack of clarity with some processes and operating policies.

"I see this as an opportunity for the BMA: to create a sense of renewal and put in place modern policies that are clear and support our members."

In a statement the BMA said, "We are aware that payments of expenses for some spouses have been made when accompanying past senior BMA member officers to international events. On some occasions spouses have been specifically invited by the host overseas national medical association. The BMA board has already acted to end such payments."

Pickersgill TP. The BMA Compensation Committee: the facts [electronic response to Kandela P. The strange world of private medicine]. BMJ 2004. bmj.com/rapid-response/ 2011/10/30/bma-compensation-committee-facts. 
2 Campbell D. Doctors' union awards secret pay hikes to senior members. Guardian. Jun 2015. www.theguardian.com/society/2015/jun/07/doctors-union-secret-pay-hikes-bma.
Published by the BMJ Publishing Group Limited. For permission to use (where not already granted under a licence) please go to http://group.bmj.com/group/rights-licensing/ permissions 